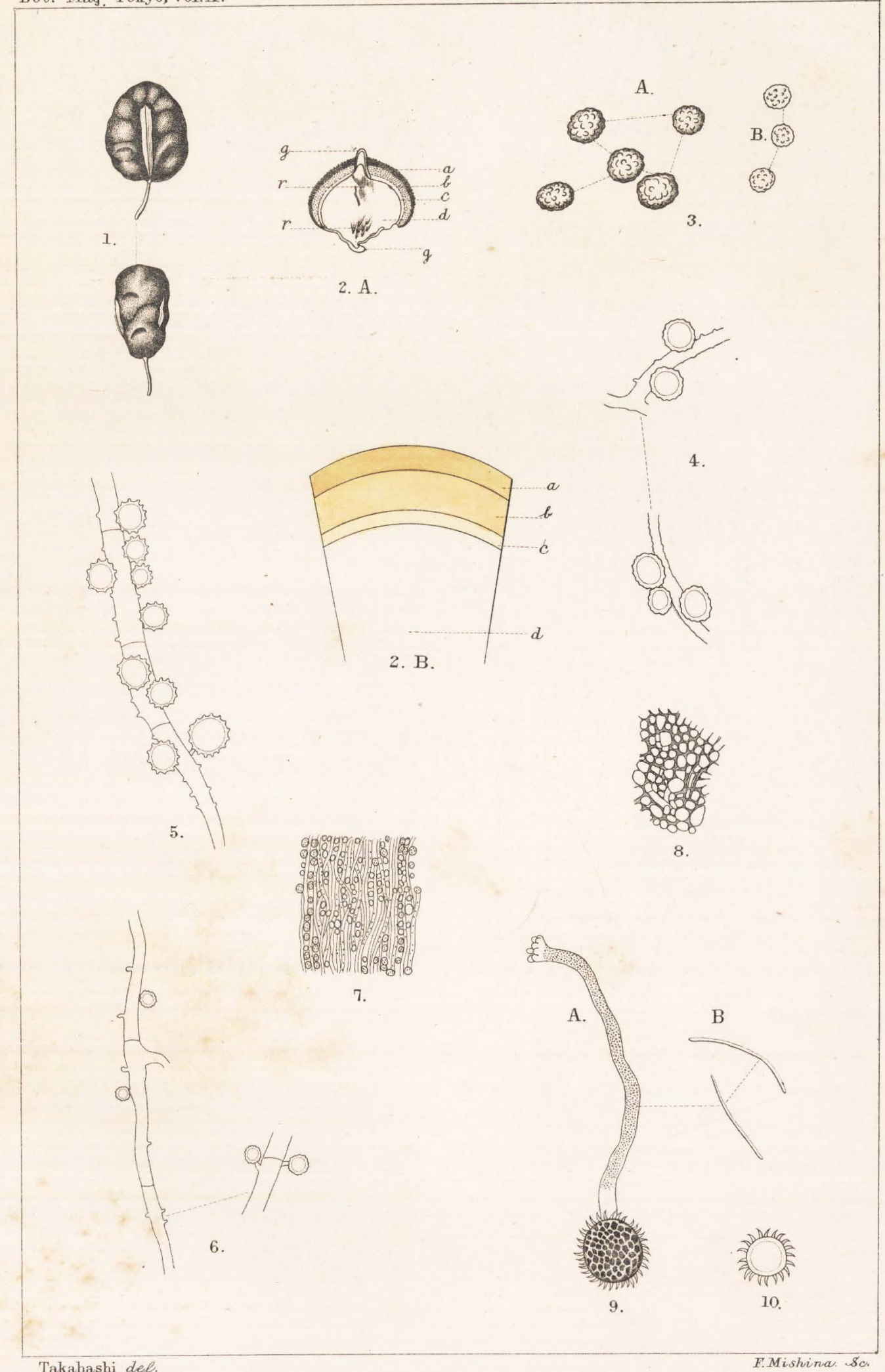




\title{
On Ustilago virens Cooke and a New Species of Tilletia parasitic on Rice-plant.
}

By

\author{
Y. Takahashi, Nōgakushi.
}

With PJ. II.

It is the object of this paper to show in detail the morphological nature of Ustilago virens Cooke ${ }^{(1)}$ and to point out that it is identical with Tilletia oryzae (2) of Patouillard, which was recently proved by Brefeld ${ }^{(3)}$ to belong to the fungi imperfecti and not to the Ustilaginea. He proved this by cultivating the spores in a nutrient solution and by showing that they reproduced the so-called smut-spores from the sclerotioid mass of hyphæ produced in the fluid. He founded a new genus, Ustilaginoidea, on this species and the another which is parasitic on Setaria. I will also take advantage of this opportunity to report on an yet undescribed species of Tilletia, which is found parasitic on rice-plant in Japan.

I am induced to do so in this connection, because it is erroneously referred by some to Tilletia oryzce Pat. and it is the only species of Ustilaginea found on Oryza sativa L. up to this time.

Ustilago virens Cooke, one of the wellknown fungi in Japan, is characterized by the formation in place of the fruit of the peculiar sporiferous body, which is at least twice as large as the normal one. These sporiferous bodies are round or oblong in shape and uneven on their surface, when fresh, resembling, in some ways the convolutions of the brain (Fig. 1). Their outer portion consists of a powdery but somewhat sticky mass of spores, which cover all the surface except the

(1) Cooke, Grevillea, Vol. VII, p. 15.

Thümen, Die Pilze der Reispflanzen, p. 3.

Saccardo, Sylloge Fungorum, Vol. VII, p. 467.

(2) Patouillard, Champignons extra européens. Bull. Soc. Myc. France, T. III, Fasc. 2. 1887, p. 124. Pl. X, Fig. 2.

Saccardo, Sylloge Fungorum Vol. IX, p. 286.

(3) Brefeld, Untersuchungen aus dem Gesammtgeb. der Mykologie, Heft XII, 1895.-Rev. in Hedwigia, Bd. XXX IV, 1895, Repert. S. 140. 
base and a part of both the flattened sides of the sporiferous bodies, which correspond to the two lateral edges of the normal fruit, where the remnants of the glumes remain forming, in a cross section, keel-like projections (Fig. 2. A, g). These spore-masses are of olivaceous green color. The coloring matter dissolves in alcohol and dilute aqueous solution of potash, giving a yellow color to the fluid. These spores are round, irregularly rounded, or sometimes angular, and 4-5 $\mu$ in diameter (Fig. 3, A). Their membrane is beset with granular protuberances and is of light olivaceous green color. The membrane becomes nearly smooth and transparent, when treated with potash solution.

If any of these sporiferous bodies be cut crosswise at their middle portion, three layers surrounding the central tissue or medulla and distinguished by their respective colors can be clearly recognized. Thus in Fig. 2 the outermost layer (a) is distinguished by its olivaceous green color; the middle (b) by its orange-yellow color; and the innermost and thinnest by its pale yellowish color. This last layer lies sometimes entirely within the middle layer, and is, in such a case, always situated nearer to the medullic. Between the keelshaped remnants of the glumes are found scattered here and there thick-walled cell remains of the tissue of the fruit embedded in the hyphal tissue of the medulla, imparting to the latter a grayish color (Fig. 2. $r$.). The tissue of these sporiferous bodies is of waxy consistence and toward the central portion notably harder.

Let us now inquire into the structure of these different portions. This point was touched upon by Mr. S. Hori of Tōkyō Agricultural Experiment Station in a previous number ${ }^{(1)}$ of this magazine, where he mentions several earlier writings ${ }^{(2)}$ on this fungus and explains its pathological and morphological nature as one of the genuine smutfungi. $\mathrm{He}$ is fairly right as far as the mere distinction of different layers in the tissue of the sporiferous bodies is concerned, but in regard to their structure, more especially to the mode of spore-formation, his statement is not correct, his figure showing the two layers composed only of spores on the outside and a layer of hyphal threads inside being decidedly erroneous.

(1) S. Hori, Diseases of Jap. ag'l plants (Jap.). This magazine Vol. VII, 1893, p. 209.

(2) N. Tanaka, On some smut-fungi (Jap.) This magazine Vol. III, p. 198.

-S. Hori, On some fungi injurious to rice plant (Jap.) This magazine Vol. IV, p. 425. etc. 
The outermost layer is the stratum of the ripe spores already described. These are not, however, the only element of which this layer is composed; for besides them there is another important element which must not be overlooked: namely the spore-hearing hyphæ. These hyphæ are hyaline, septate, little branched, about $25 \mu$ in thickness, and traverse almost vertically to the onter surface. The spores are borne singly on the short projections or sterigmata, as they may be called, which seem to be scattered on the hyphæ without any regularity (Figs. 4 and 5). The spores are sometimes so thickly borne on the hypha that the latter are almost entirely covered by the former. When the spores are removed, the hypha show a tubercular surface under a low magnification. The middle or orange-colored layer is the stratum of the young spores and the hyphæ similar to those in outer (Figs. 6, 7). Here it is more distinctly seen that the hyphæ run almost parallel in a radial manner toward the outer surface. These young spores are pale in color and about $3 \mu$ in diameter, their membrane being nearly smooth or slightly uerrucose (Fig. 3, B.) The third and represents thinnest layer of pale yellowish color the still younger portion and is of the same structure as the middle just discribed.

The medulla consists of thin, hyaline hyphæ forming a kind of sclerotia (Fig. 8). These hyphæ are septate and seldom branched. Toward the outer portion they become arranged more and more in parallel series, increase also in thickness and then turn to spore-bearing hyphæ. Thus we see that what we have designated as medulla is nothing but the stroma of the fungus, from which the spore-bearing hyphae spring out, and that the mode of spore-formation in this case is entirely different from that in the Ustilaginece. We see further that the fungus under consideration is a species of the Hyphomycetes, and not of the Ustilaginece.

We shall now try to show that it is identical with Tilletia Oryzo Pat. This latter species is described by Patouillard ${ }^{(1)}$ as follows :-

"Spores globuleuses on ovoides, mesurant 3 á $5 \mu$ de diameter, brunes olivâtres, verrugueuses, reunies en une masse dure d'un noir verdâtre mélangées des filaments griles, incolores, á bordes irregulières.

"Attaque le fruit du riz, qui devient volumineaux, noir et dur comme un sclérot."

(1) Loc. cit. 
The above description ${ }^{(1)}$ accords well with the general character of Ustilago virens Cooke, which we have studied; and moreover Patouillard's figures showing the general appearance of the fungus-body and the spores, strongly suggest the idea that he had redescribed $U$. virens Cooke under a different name. Further, as already stated, the spores of Tilletia Oryzce Pat. mere proved by Brefeld to produce in nutrient solution the sclerotioid mass of hyphæ, which is capable of reproducing the so-called smut-spores. From this highly interesting result two things are obvious: (1) Tilletia Oryzce Pat. does not belong properly to the Ustilaginea, because, unlike all other smut-fungi, it reproduces the spores in a nutrient solution; (2) the sclerotioid mass of hyphæ it produces in nutrient solution corresponds to the above described medulla or stroma of Ustilago virens Cooke. We can therefore conclude, with a considerable degree of safety, that Ustilago virens Cooke, is the same as Tilletia Oryzce Pat., now Ustilaginoidea Oryzce (Pat.) Brefeld. But, in as much as the publication Cookes description antedates that of Patonillard's the name of the fungus must be changed Ustilaginoidea virens (Cooke).

Let us now turn to the consideration of a new species of Tilletia found on Oryza sativa L. My original specimen was found among the ears of rice sent from Kyôto for seed-material. It consisted of only a few diseased grains which were of ordinary form and size, but notably lighter in color than sound ones. Their interior was filled up with powdery black spores which easily escaped from the fissures of husks. On examining the spores under a microscope I was struck at once by the highly developed acute spines on their epispore. These spines are hyaline or slightly colored and more or less curved, thus giving a peculiar appearance to the spores. The spores are round or broadelliptical and deep olive-brown in color. They germinated in three days in the early part of September (1895), when they have been sown in water. The promycelial tubes varied much in their length and formed toward their free end 1-3 cross septa. The filiform or needleshaped sporidia were formed in a characteristic manner on the end of the promycelial tube. After falling away from the promycelium the sporidia produced cross septa ( 2 or 3 in number) as in the case of

(1) Compare with the description of $U$. virens Cooke, which is given in Sauordo (loc. cit.) as follows:- "Pulverulent, effusa, olivaceo-virens; sporis globosis, olivaceo-fuscis; episporio granuloso, $5 \mu$. diam." 
Tilletia tritici (Bjerk.); but the well-known H-shaped conjugation of the sporidia was not observed in this case. The similar specimen collected in the vicinity of Tōkyö was also obtained through the kindness of Mr. S. Hori. A description of this species may be given as follows :-

Tilletia horrida nov. sp.--Spore-masses pulverulent, black, produced within the ovary and remaining covered by the glumes. Spores globose, irregularly rounded, or sometimes brood-elliptical, the round ones $18.5-23.0 \mu$ in diameter and the elongated $22.5-26.0 \times 18.0-22.0 \mu$ in size. Epispore deep olive brown, opaque, thickly covered with conspicuous spines. The spines hyaline or slightly colored, pointed at the apex, irregularly polygonal at the base, more or less curved 2.5-4.0 $\mu$ in height, and 1.5-2 $\mu$ apart at their free ends. Sporidia filiform or needle-shaped, curved in various mays, 10-20 in number and 38-53 $\mu$ in length. Hab. On Oryza sativa L. From Tōkyō and Kyōto.

\section{Botanical Laboratory, Sapporo Agricultural College, Hokkaidō, Feb. 25, 1896.}

\section{EXPLANATION OF FIGURES.}

\section{Ustilaginoidea virens (Cooke.) (Figs. 1-8 incl.)}

Fig. 1.-A sporiferous body seen from different sides. After S. Hori, magn. 2 times.

Fig. 2.-A cross-section af the sporiferous body; $a$ the outermost layer, $b$ the middle, $c$ the innermost, $d$ medulla, $g$ remnants of the glumes, $r$ remains of thick-walled celis of the tissue of the fruit. Magn. 3 times. B a port of the same section diagrammatically represented. Magn. about 10 times.

Fig. 3.-A ripe spores; $\mathbf{B}$ young spores in the middle layer. Magn. 880 times.

Fig. 4.-Spore-bearing hyphæ in the outermost layer. Magn. 880 times.

Fig. 5.-Spore-bearing hyphæ in the outermost layer, whose spores are not yet fully mature. Magn. 880 times.

Fig. 6.-Spore-bearing hyphæ in the middle layer. Magn. 880 times.

Fig. 7.-Cross-section of a part of the middle layer, showing the arrangement of sporebearing hyphæ. Magn. 380 times.

Fig. 8.-Thin cross-section through the central portion of medulla. Magn. 880 times.

Tilletia horrida, nov. sp. (Figs. 9-10 incl.).

Fig. 9.-A a spore which had germinated in water; B sporidia. Magn. 380 times. Fig. 10.-An immature spore with excessively developed spines. Magn. 380 times. 